\title{
KONSEP KEADILAN EKOLOGI DAN KEADILAN SOSIAL DALAM SISTEM HUKUM INDONESIA ANTARA IDEALISME DAN REALITAS
}

\author{
Elly Kristiani Purwendah \\ Fakultas Hukum \\ Universitas Wijayakusuma Purwokerto \\ Email : elly_kristiani@yahoo.co.id
}

\begin{abstract}
ABSTRAK
Keadilan lingkungan berdasarkan taksonomi keadilan dibagi dalam empat katagori (yaitu, keadilan lingkungan sebagai keadilan distributif, keadilan lingkungan sebagai keadilan korektif, keadilan lingkungan sebagai keadilan prosedural dan keadilan lingkungan sebagai keadilan sosial. Dalam pembahasan perumusan permasalah ini, keadilan lingkungan sebagai keadilan sosial. Penulis mengartikan keadilan lingkungan sosial digunakan berbarengan untuk memperkuat pemahaman mengenai keadilan lingkungan sebagai sebuah keadilan sosial.
\end{abstract}

Kata kunci : keadilan, lingkungan, sosial

\section{ABSTRACT}

Environmental justice based on taxonomy of justice is divided into four categories, namely, environmental justice as distributive justice, environmental justice as corrective justice, environmental justice as procedural justice and environmental justice as social justice. In discussing the formulation of this problem, environmental justice is social justice. The author means that social environmental justice is used together to strengthen the understanding of environmental justice as a social justice.

Keywords: justice, environment, social

\section{Pendahuluan}

Wilayah laut Indonesia yang mencapai luas 3,11 juta $\mathrm{km}^{2}$ menyebabkan potensi sektor kelautan menjadi tidak ternilai (Siahaan, 2018), terutama dari sektor kekayaan alam lautnya (Lilley, 1999). Potensi kekayaan laut menjadi sedemikian penting sebagaimana diprioritaskan oleh Indonesia dalam Konsep green economy dan blue economy yang bermuara pada pembangunan berkelanjutan sebagaimana disampaikan oleh Presiden RI saat memberikan sambutannya dalam Konferensi Rio+20 (United Nations Conference on Suistanable Development) di Rio de Jeneiro, Brasil pada tanggal 20-22 Juni 2012.

Lingkungan laut merupakan bagian dari perekonomian suatu negara (Gore, 1995). Dengan panjang garis pantai sekitar $95.181 \mathrm{~km}$, perairan Indonesia memiliki potensi yang tinggi. Ukuran tersebut merupakan urutan kedua setelah Kanada sebagai Negara yang memiliki garis pantai kedua terpanjang di dunia. Nilai perekonomian dari laut ditaksir 
mencapai US\$3 triliun - US\$5 triliun atau setara dengan Rp. 36.000 triliun - Rp. 60.000 triliun per tahun (Media Keuangan; 2015). Angka ini belum termasuk potensi lain yang berasal dari kekayaan bioteknologi, wisata bahari maupun pengembangan transportasi laut. Potensi maritim Indonesia yang demikian besar ditangkap sebagai salah satu visi misi unggulan pada pemerintahan presiden Jokowi saat ini. Selain itu, potensi besar ekonomi dan ekologi yang tersimpan sebagai negara maritim, potensi kerusakan alam yang dapat ditimbulkan akibat eksplorasi berlebihan yang dapat mengancam keberlanjutan pembangunan hendaknya juga mendapat perhatian. Untuk itu, saat ini pemerintah tengah mendorong kebijakan ekonomi maritim dengan model ekonomi biru (http://prasetya.ub.ac.id). Pada dasarnya ekonomi biru menggabungkan pengembangan ekonomi dan pelestarian lingkungan.

Hukum dalam fungsinya sebagai perlindungan kepentingan manusia mempunyai tujuan. Agar kepentingan manusia terlindungi, hukum harus dilaksanakan. Pelaksanaan hukum dapat dilakukan baik secara normal, damai atau terjadi karena adanya pelanggaran hukum. Dalam hal terjadi pelanggaran hukum, maka hukum yang dilanggar haruslah ditegakkan. Melalui penegakkan hukum inilah hukum menjadi sebuah kenyataan. Dalam penegakkan hukum ada tiga unsur yang harus diperhatikan yaitu, kepastian hukum (rechtssicherheit), kemanfaatan (zweckmassigkeit) dan keadilan (gerechtigkeit) (Sudikno;145). Kepastian hukum merupakan perlindungan yustisiabel terhadap tindakan sewenang- wenang, yang berarti bahwa seseorang akan memperoleh sesuatu yang diharapkan dalam keadaan tertentu. Masyarakat mengharapkan adanya kepastian hukum untuk ketertiban. Hukum dalam hal ini bertugas menciptakan kepastian hukum karena bertujuan untuk ketertiban masyarakat. Masyarakat dalam hal lain, mengharapkan manfaat dalam pelaksanaan atau penegakkan hukum. Hukum adalah untuk manusia, sehingga pelaksanaan atau penegakkannya haruslah memberi manfaat bagi manusia. Keadilan sebagai unsur ketiga sangatlah dibutuhkan oleh masyarakat, di dalam pelaksanaannya hukum haruslah adil karena hukum tidak identik dengan keadilan. Keadilan sangatlah bersifat subyektif, individualistis dan tidak menyamaratakan. Dalam penegakkan hukum diperlukan kompromi antara ketiga unsur tersebut, meskipun dalam praktek sangat sulit mengkompromikan tiga hal tersebut secara proporsional.

Tujuan pokok hukum adalah menciptakan tatanan masyarakat yang tertib, menciptakan ketertiban dan keseimbangan. Dengan tercapainya ketertiban dalam masyarakat diharapkan kepentingan manusia akan terlindungi. Dalam mencapai tujuannya, hukum bertugas membagi hak dan kewajiban antar perorangan di dalam masyarakat, membagi wewenang dan mengatur cara memecahkan masalah hukum serta 
memelihara kepastian hukum (Sudikno;1999). Hukum sematamata bertujuan untuk keadilan. Isi hukum ditentukan oleh keyakinan kita yang etis tentang yang adil dan tidak. Dengan kata lain, hukum bertujuan untuk merealisir atau mewujudkan keadilan. Keadilan menyangkut dua hal, yaitu menyangkut hakekat keadilan dan menyangkut isi atau norma untuk berbuat secara konkrit dalam keadaan tertentu.

\section{Pembahasan}

\section{Teori Sistem Hukum}

Pembahasan mengenai sistem hukum diawali dengan pemahaman oleh Friedman bahwa, di dalam sistem hukum tercakup tiga eleman yaitu, struktur, substansi dan kultur hukum. Sistem hukum adalah suatu atau tatanan yang teratur dari berbagai unsur menjadi suatu keharusan yang saling menguatkan untuk mencapai tujuan. Sistem hukum diciptakan agar tidak terjadi tumpang tindih antar sistem itu sendiri, sistem hukum ini berlaku dengan baik apabila didukung dengan asas hukum yang baik pula. Sistem hukum mengatur segala aktivitas kehidupan manusia sejak lahir sampai meninggal dunia bahkan mengatur orang yang masih di dalam kandungan dengan syarat lahir hidup (Iskandarsyah, 2008).

Lawrence M. Friedman mengemukakan bahwa sistem hukum sesungguhnya dibangun oleh tiga komponen, yaitu substansi hukum (legal substance), struktur hukum (legal structure), dan budaya hukum (legal culture) (Friedman, 2001). Ketiga komponen sistem hukum tersebut sesungguhnya bersifat komplementer dan berada dalam suatu hubungan fungsional. Untuk menegakkan supremasi hukum, ketiga komponen sistem hukum tersebut harus dikembangkan secara simultan dan integral:

1.Struktur Sistem hukum mempunyai struktur kerangka, bagian yang tetap bertahan, bagian yang memberi semacam bentuk dan batasan terhadap keseluruhan. Komponen ini menunjuk adanya kelembagaan yang diciptakan oleh sistem hukum lembaga-lembaga mana mempunyai pelekatan, fungsifungsi tersendiri di dalam bekerjanya sistem hukum tersebut. Lembaga-lembaga ini antara lain adalah Lembaga Kepolisian, Lembaga Kejaksaan, Lembaga Pengadilan dan Lembaga Kepengacaraan. Secara singkat dapat dikatakan bahwa komponen yang bersifat struktural ini memungkinkan masyarakat untuk mengharapkan bagaimana suatu sistem hukum itu seharusnya bekerja (law in the books) (Soekanto, et. all., 1986).

2.Substansi Substansi adalah aturan, norma, dan pola perilaku nyata manusia yang berada dalam sistem itu. Substansi juga berarti "produk" yang dihasilkan oleh orang yang berada di dalam sistem hukum itu keputusan yang mereka keluarkan, aturan baru yang mereka susun.

3. Budaya Hukum (Kultural) Budaya hukum adalah sikap manusia terhadap hukum dan sistem hukum kepercayaan, nilai, pemikiran serta harapannya. Dengan kata lain, budaya hukum 
adalah suasana pikiran sosial dan kekuatan sosial yang menentukan bagaimana hukum digunakan, dihindari, atau disalah gunakan. Dalam Soerjono Soekanto dikatakan jika komponen yang bersifat struktural dapat diibaratkan sebagai suatu mesin, maka komponen kultural dapat diibaratkan sebagai bensin, yang merupakan penggerak dari mesin tadi. Dalam hal ini yang menjadi masalah adalah nilai dan sikap daripada fungsionaris yang bekerja dalam lingkungan pelaksanaan dan penegakan hukum. Komponen nilai dan sikap ini akan memberi pemahaman tentang bekerjanya suatu sistem hukum di dalam kenyataan (law in action).

Upaya membentuk suatu produk hukum yang dapat diterima sebagai suatu norma, khususnya bagaimana suatu produk hukum menjamin hak asasi warga negara, harus memperhatikan tiga aspek penting yang berhubungan dengan pemberlakuan kaidah hukum tersebut, yaitu:

1. Aspek Yuridis, artinya adalah bahwa penentuannya berdasarkan kaidah yang lebih tinggi tingkatannya (tidak boleh bertentangan dengan suatu produk hukum yang lebih tinggi tingkatannya) dan juga dibentuk menurut cara yang telah ditetapkan.

2. Aspek Sosiologis, artinya adalah efektivitas kaidah hukum dalam kehidupan bersama. Mengenai hal ini dikenal dua teori, yaitu teori kekuasaan yang pokoknya menyatakan bahwa kaidah hukum mempunyai kekuatan sosiologis apabila dipaksakan berlakunya oleh penguasa, diterima ataupun tidak oleh warga masyarakat dan teori pengakuan yang berpokok pangkal pada pendapat bahwa kelakuan kaidah hukum didasarkan pada penerimaan atau pengakuan masyarakat di mana kaidah hukum tersebut akan diberlakukan.

3. Aspek Filosofis, artinya kaidah hukum tersebut sesuai dengan citacita hukum sebagai nilai positif tertinggi, misalnya Pancasila, masyarakat adil dan makmur, dan seterusnya.

Identifikasi sistem hukum juga dilakukan oleh Brian Tamanaha sebagai :

(1) legal system are comprehensive in the sense that claim authority to regulate any type of behavior;

(2) legal system claim supremacy over all other institualized normative system in society;

(3) legalsystemreopensysteminthesense that theymaintainandsupport other from of social grouping.

(1) sistem hukum bersifat komprehensif dalam arti mengklaim otoritas untuk mengatur semua jenis perilaku;

(2) sistem hukum mengklaim supremasi atas semua sistem normatif lain yang dilembagakan di masyarakat;

(3) sistem hukum membuka kembali sistem dalam arti bahwa sistem hukum mempertahankan dan mendukung bentuk lain dari pengelompokan sosial.

Teori sistem hukum sangat dibutuhkan pada pembahasan mengenai analisa dan efektivitas hukum dalam penerapannya, khususnya dalam menganalisa nilai keadilan dalam penerapan ganti kerugian pencemaran minyak oleh 
kapal tanker di Indonesia.

\section{Konsep Keadilan Ekologi Dan Keadilan Sosial Dalam Sistem Hukum Indonesia Antara Idealisme Dan Realitas}

Hakekat keadilan adalah pernilaian suatu perlakuan atau tindakan, mengkajinya dengan suatu norma yang menurut pandangan subyektif (subyektif untuk kepentingan kelompoknya, golongannya dan sebagainya) melebihi norma-norma lain. Dalam hal ini ada dua pihak yang terlibat, yaitu pihak yang memperlakukan dan pihak yang menerima perlakuan. Hukum bukanlah hanya sekedar kumpulan peraturanperaturan yang berdiri sendirisendiri. arti pentingnya suatu peraturan hukum adalah hubungannya yang sistematis dengan peraturan hukum yang lain. Hukum sebagai sebuah sistem memiliki arti bahwa, hukum itu merupakan tatanan, kesatuan yang utuh yang terdiri dari bagian- bagian atau unsur-unsur yang saling berkaitan erat satu sama lain. Sistem hukum merupakan satu kesatuan yang terdiri dari unsur-unsur yang mempunyai interaksi satu sama lain dan bekerja sama untuk mencapai tujuan kesatuan tersebut. Kesatuan tersebut diterapkan terhadap kompleks unsur-unsur yuridis seperti peraturan hukum, asas hukum dan pengertian hukum.Asas hukum adalah kecenderungankecenderungan yang disyaratkan oleh pandangan kesusilaan kita pada hukum, merupakan sifat-sifat umum dengan segala keterbatasannya sebagai pembawaan yang umum itu, tetapi yang tidak boleh tidak harus ada. Asas hukum merupakan prinsip hukum, dalam hal ini bukanlah peraturan hukum konkrit melainkan merupakan pikiran dasar yang umum sifatnya atau merupakan latar belakang dari peraturan yang konkrit yang terdapat dalam dan dibelakang setiap sistem hukum yang terjelma dalam peraturan perundangundangan dan putusan hakim yang merupakan hukum positif dan dapat diketemukan dengan mencari sifatsifat umum dalam peraturan konkrit tersebut (Scholten, 1935).

Penegakkan dalam sistem hukum lingkungan memerlukan salah satu unsur penegakkan hukum yaitu, keadilan. Keadilan lingkungan bukanlah sebuah konsep yang memiliki berbagai definisi. Collin melihat keadilan lingkungan terutama dalam kaitannya dengan distribusi hak dan manfaat lingkungan secara adil diantara ras, kelas dan pendapatan masyarakat. Menurut Collin, aspek prosedural berupa partisipasi publik dalam pengambilan keputusan dianggap termasuk ke dalam hak subtantif yang merupakan bagian dari keadilan distributive (Collin, 2008;414). Keadilan lingkungan tidak hanya memuat aspek distribusi, tetapi juga aspek prosedural sebagaimana pandangan Arcioni dan Mitchell yang menyatakan bahwa, selain terkait aspek distribusi, keadilan lingkungan juga terkait dengan kesempatan publik untuk berpartisipasi dalam pengambilan keputusan terkait pengelolaan lingkungan (Millner, 2003).

Pandangan yang melihat keadilan lingkungan lebih luas dari persoalan 
distribusi dan prosedural. Bullard mengidentifikasi lima elemen dasar dari keadilan lingkungan yang meliputi :

1.hak individu untuk dilindungi dari pencemaran;

2. preferensi terhadap pencegahan pencemaran;

3. beralihnya beban pembuktian pada mereka atau mereka yang membuang;

4. limbah/emisi (dischargers) atau pada mereka yang tidak memberikan perlakuan yang berbeda, tetapi berdasarkan adanya perbedaan dampak lingkungan yang dirasakan oleh masyarakat (disparate impacts) dan

bukti statistik yang menunjukkan perbedaan itu, dan;

5. perbedaan pembagian risiko diatasi dengan tindakan dan sumber daya

yang tertarget (targeted action and resources) (Bullard, 1994;10).

Keadilan

lingkungan

berdasarkan taksonomi keadilan dibagi dalam empat katagori (Kuehn, 2000) yaitu, keadilan lingkungan sebagai keadilan distributif, keadilan lingkungan sebagai keadilan korektif, keadilan lingkungan sebagai keadilan prosedural dan keadilan lingkungan sebagai keadilan sosial. Dalam pembahasan perumusan permasalah ini, keadilan lingkungan sebagai keadilan sosial. Kuehn mengartikan keadilan lingkungan sosial digunakan berbarengan untuk memperkuat pemahaman mengenai keadilan lingkungan sebagai sebuah keadilan sosial.

Sebagai sebuah istilah, sesungguhnya ekologi mulai pertama digunakan oleh seorang ahli biologi Jerman Ernst Haekel yang mengartikannya sebagai ilmu tentang relasi diantara organisme dan dunia luar sekitarnya. Bersamaan dengan itu, digunakan juga istilah lingkungan hidup (environment) yang harus dipahami sebagai padanan yang terpisahkan antara hidup dan lingkungan atau lingkungan dan hidup yang terkait satu sama lain. Disini lingkungan hidup dipahami sebagai sama artinya dengan ekologi sebagai berkaitan dengan kehidupan organisme (termasuk manusia) dan ekosistemnya serta interaksi diantaranya. Ekosistem sendiri disini dipahami sebagai sebuah komunitas organisme dan lingkungan fisiknya yang berinteraksi sebagai sebuah ekologis (Capra, 1996;42). Prinsip-prinsip ekologis, dimaksudkan Capra sebagai, prinsip jejaring (networks), siklus (cycles), energi surya (solar energy), kemitraan (partnership), keanekaragaman (diversity) dan keseimbangan dinamis (dynamic balance) (Capra, 2003). Pertama, Prinsip jejaring diartikan sebagai sistem kehidupan yang berkembang dalam sistem kehidupan lainnya, sebagai jejaring dalam jejaring.

Setiap sistem kehidupan saling berkomunikasi dengan sistem kehidupan lainnya dan saling berbagi sumber daya yang memungkinkan setiap sistem kehidupan dapat berkembang dalam identitasnya masing-masing. Semua makhluk hidup adalah mahluk hidup yang punya batas- batas spasial (boundary creatures), tetapi mahluk hidup itu termasuk manusia terkait dan merupakan bagian dari sistem relasi yang tergantung satu 
sama lain (McGinnis, 1999). Kedua, Prinsip siklus merupakan prinsip daur ulang, semua organisme hidup dengan sendirinya hidup dan berkembang berkat pasokan energi dan materi sebagai makanannya dari rangkaian tak terputus pasokan energi dan materi dari lingkungan tempat setiap organisme hidup dan berkembang. Bersamaan dengan itu, setiap sistem kehidupan terus menerus memproduksi sisa proses produksi sebagai limbah yang akan bermanfaat sebagai energi dan materi untuk kehidupan organisme lainnya. Ketiga, prinsip energi matahari. Yang dimaksud disini adalah energi surya bukan sebagai sebuah fakta alam melainkan sebagai sebuah prinsip penting dalam alam. Keempat,

Prinsip kemitraan. Prinsip ini menjelaskan bahwa pertukaran energi dan sumber daya di dalam ekosistem atau alam semesta ini hanya mungkin terjadi melalui kerjasama yang melingkupi seluruh jaring kehidupan. Kehidupan di alam semesta berlangsung bukan dengan perang dan persaingan untuk saling mengalahkan satu sama lain, melainkan melalui kerjasama, kemitraan dan jaringan. Kelima, prinsip keanekaragaman. Semakin tinggi keragaman kehidupan di alam, semakin ekosistem tahan terhadap berbagai goncangan, hambatan dan rintangan. Pola kehidupan yang seragam akan dengan sendirinya secara alamiah mematikan kehidupan karena bertentangan dengan hakikat kehidupan yang beragam. Sebaliknya, pola kehidupan yang beragam, multikultur akan melestarikan

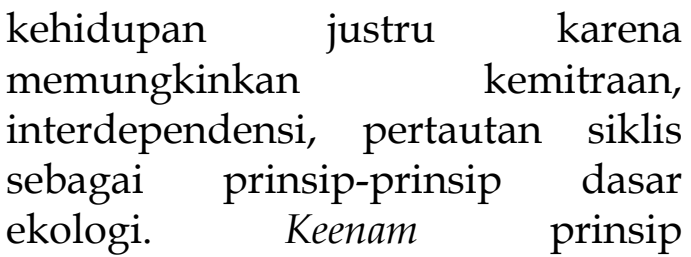

keseimbangan dinamis. Ekosistem pada dasarnya merupakan jaringan yang fleksibel dan berfluktuasi tanpa henti. Fleksibilitasnya merupakan konsekwensi dari rangkaian kelokan umpan balik yang memungkinkan sistem tersebut tetap bertahan dalam keseimbangan dinamis. Oleh karenanya diperlukan adanya sebuah komunitas manusia yang berkelanjutan dengan mendasarkan diri pada prinsip-prinsip ekologis yang berlaku dalam komunitas ekologis. Komunitas manusia yang telah salah dikelola karena meninggalkan prinsip-prinsip ekologis harus kembali ditata ulang sejalan dengan prinsip kehidupan dalam komunitas ekologi.

Manusia dalam pemahaman ekosentrisme adalah bagian tak terpisahkan dari komunitas ekologis, komunitas manusia pun harus ditata ulang berdasarkan prinsip-prinsip ekologis diatas. Dengan jalan itu, kita akan berhasil mengatasi berbagai krisis dan bencana ekologis dan dengan itu pembangunan komunitas manusia yang berkelanjutan dapat terwujud. Dalam hal keadilan lingkungan (ekologi) dipandang sebagai sosial, Kuehn mengatakan bahwa keadilan lingkungan sebagai keadilan sosial merupakan cabang dari keadilan yang akan mendorong kita untuk melakukan upaya terbaik guna mencapai tatanan masyarakat yang mampu memenuhi kebutuhan hidup masyarakat.

Keadilan sosial meminta bahwa 
setiap anggota masyarakat memiliki sumber daya dan kekuasaan yang cukup untuk hidup secara layak sebagai manusia. Prinsip keadilan lingkungan sebagai keadilan sosial meminta adanya alternatif sistem ekonomi yang mampu memberikan kontribusi pada pembangunan yang ramah lingkungan, mendukung pembebasan masyarakat secara politik, ekonomi dan budaya, memajukan kebijakan berdasarkan saling menghormati, keadilan bagi semua orang, dan tanpa diskriminasi, mendorong terjadinya pemulihan lingkungan baik perkotaan maupun desa, menghormati integritas budaya masyarakat dan menyediakan akses bagi semua masyarakat atas sumber daya yang dimiliki oleh masyarakat. Keadilan lingkungan sebagai sebuah keadilan sosial berkaitan secara fungsional dan empiris dengan pembangunan berkelanjutan. Pembangunan berkelanjutan (sustainable development) merupakan pembangunan yang memenuhi kebutuhan generasi sekarang tanpa mengurangi kemampuan generasi yang akan datang dalam memenuhi kebutuhannya.

Keadilan sosial oleh Kamus Besar Bahasa Indonesia diartikan sebagai, "mempertahankan hak atau kerjasama untuk menghasilkan masyarakat yang bersatu secara organis sehingga setiap anggota masyarakat memiliki kesempatan yang sama dan nyata untuk tumbuh dan belajar hidup pada kemampuan aslinya" (Departemen Pendidikan dan Kebudayaan, 1999). Black Law Dictionary mengartikan keadilan sosial (social justice) sebagai, "Justice that conforms to a moral principle, such as that all people are equal" (Garner (ed), 2011). Keadilan sosial bukanlah masalah moral individu, tetapi masalah sosial yakni terkait dengan persoalan-persoalan strukural yang bersifat impersonal. Artinya pelaksaan keadilan sosial tidak ditentukan oleh kehendak baik buruk individu tertentu, tetapi bergantung kepada strukturstruktur kekuasaan yang ada di masyarakat, seperti struktur ekonomi, politik dan budaya. Keadilan sosial menuntut bahwa manfaat-manfaat sosial yang tersedia di masyarakat harus didistribusikan sedemikian rupa sehingga menyentuh anggota masyarakat yang paling kurang beruntung. Makna keadilan sosial yang diharapkan tidak terlepas dari sifat relasionalnya dipahami sebagaimana pendekatan yang ditawarkan oleh Amartya Sen yang memaparkan konstelasi jenis-jenis keadilan melalui 2 (dua) pendekatan, yaitu : (Sen, 2009)

1. Pendekatan transendental (transcendental

institutionalism) Identifikasi tentang keadilan adalah dengan mencari dan menetapkan karakteristik sosial yang adil untuk kemudian membentuk sebuah pranata

atau institusi sosial yang mampu menegakkan prinsip-prinsip moral.

2. Pendekatan perbandingan realita (realization focused comparison)

Upaya yang dilakukan pendekatan ini untuk merumuskan makna keadilan adalah tidak dengan jalan merumuskan karakteristik sosial dan membentuk institusiinstitusi sosial. Melalui pendekatan ini, keadilan pertama-tama dilihat dari segi kenyataan yaitu kondisi 
masyarakat yang tidak adil sehingga keadilan adalah usaha untuk membongkar atau merubah tatanan yang tidak adil tersebut.

Untuk merepresentasikan muatan keadilan lingkungan yang memenuhi makna keadilan sosial diperlukan sebuah karakteristik sosial yang adil. Karakteristik sosial yang adil dapatlah dipenuhi melalui penerapan prinsip-prinsip hukum lingkungan internasional. Integrasi prinsip-prinsip hukum lingkungan global ke dalam hukum nasional Indonesia diadopsi melalui dua mekanisme yaitu:

1. melalui ratifikasi internasional hard law instruments di bidang lingkungan hidup;

2. melalui adopsi langsung dengan memasukkan prinsip-prinsip tersebut dalam peraturan perundang-undangan lingkungan nasional Indonesia.

UUD 1945 merupakan supremasi konstitusi dan hierarki perundang-undangan dalam suatu sistem hukum yang mengandung konsekuensi. Konsekuensinya, semua ketentuan perundangundangan yang telah ada dan yang akan dibentuk termasuk perubahan ketentuan perundang-undangan, materi muatannya harus bersumber pada ketentuan dalam UUD 1945. Tujuannya agar terdapat kesesuaian norma sebagai satu kesatuan sistem hokum (Bachrie, 2011). Menurut Koesnadi Hardjasoemantri, kaidah dasar yang melandasi pembangunan dan perlindungan hidup di Indonesia terdapat dalam Pembukaan UUD 1945 pada alinea ke-4 yang berbunyi : Kemudian daripada itu, untuk membentuk suatu pemerintahan negara
Indonesia yang melindungi segenap bangsa Indonesia dan seluruh tumpah darah Indonesia dan untuk memajukan kesejahteraan umum dan mencerdaskan kehidupan bangsa dan ikut melaksanakan ketertiban dunia yang mendasarkan kemerdekaan, perdamaian abadi dan keadilan sosial, maka disusunlah kemerdekaan kebangsaan Indonesia yang terbentuk dalam suatu susunan Negara Republik Indonesia.

Ketentuan ini menegaskan kewajiban negara dan tugas pemerintah untuk melindungi segenap bangsa dan tumpah darah Indonesia dalam lingkungan hidup. Konteks segenap bangsa Indonesia dimaknai sebagai sumber-sumber insani lingkungan hidup, yang mengartikan manusia sebagai satu kesatuan sosio sistem. Sedangkan seluruh tumpah darah Indonesia, dimaknai sebagai komponen fisik yang membentuk biotic community (komunitas benda hidup) dan abiotic community (komunitas benda mati).

Penjabaran tugas pemerintah sebagaimana disebutkan dalam Pembukaan UUD 1945 juga dapat ditemukan dalam Pasal 33 UUD 1945, yang menyatakan bahwa, "bumi dan air dan kekayaan alam yang terkandung di dalamnya dikuasai oleh negara dan digunakan untuk sebesar-besarnya kemakmuran rakyat" (Siombo, 2010). Pasal33 Ayat 3 UUD 1945 mengisyaratkan tugas pemerintah untuk melindungi segenap bangsa Indonesia, termasuk di dalamnya lingkungan hidup. Dalam konteks ini secara jelas dan tegas disebutkan kontrak yang terjadi antara hak umum (negara) dan hak pribadi 
(warga negara) dalam memanfaatkan lingkungan hidup termasuk sumber daya didalamnya. Dengan kata lain, negara wajib melindungi dan menjaga lingkungan hidup agar rakyat menjadi makmur dan sejahtera. Dalam Pembukaan UUD 1945, alinea ke-4 dan Pasal 33 Ayat 3 UUD 1945 dapat ditemukan penjabaran konkret ketentuan Pasal 33 Ayat 4 UUD 1945 dan Pasal $28 \mathrm{H}$ Ayat 1 UUD 1945. Pasal 33 ayat 4 UUD 1945 menyatakan bahwa; perekonomian nasional diselenggarakan berdasar atas demokrasi ekonomi dengan prinsip kebersamaan, efisiensi berkeadilan, berkelanjutan, berwawasan lingkungan, kemandirian, serta dengan menjaga keseimbangan kemajuan dan kesatuan ekonomi sosial.

Pasal 33 ayat 4 UUD 1945 berupaya mengintegrasikan pengembangan ekonomi dengan isu-isu demokrasi, solidaritas, efisiensi, keadilan, berkelanjutan dan prinsip-prinsip lingkungan lainnya. Pasal 33 Ayat 4 UUD 1945 masih diinformasikan ke dalam bahasa yang bersifat umum sehingga membutuhkan penjabaran lebih lanjut dalam bentuk aturan yang lebih rendah dan atau membutuhkan interpretasi dari pengadilan. Pasal $28 \mathrm{H}$ Ayat 1 UUD 1945 lebih lanjut menyebutkan bahwa, "setiap orang berhak hidup sejahtera lahir dan batin, bertempat tinggal dan mendapatkan lingkungan hidup yang baik dan sehat serta berhak memperoleh pelayanan kesehatan". Pasal $28 \mathrm{H}$ Ayat 1 UUD 1945 secara tegas menyatakan pengakuan Indonesia atas hak-hak lingkungan sebagai bagian dari hak-hak dasar (hak asasi manusia) masyarakat Indonesia. Keberadaan Pasal 28 H Ayat 1 UUD 1945 ini untuk menunjukkan bahwa konstitusionalisasi lingkungan bertujuan agar tidak ada lagi kebijakan dan peraturan perundangundangan di bawah UUD 1945 yang bertentangan UUD 1945 yang telah pro-lingkungan (Asshiddiqie, 2009).

Keberadaan Pasal 33 Ayat 4 UUD 1945 dan Pasal 28 H Ayat 1 yang pro- lingkungan hidup oleh Jimly Asshiddiqie disebut sebagai green constitution (konstitusi hijau) (green constitution dalam lintas batas perkembangan ketatanegaraan khususnya negara-negara dunia sebenarnya bukan merupakan sesuatu yang baru. Dalam konteks Indonesia wacana green constitution sebagai istilah memang belum terlalu lama diperkenalkan. Namun demikian, bagi mereka yang sifatnya aktif dan bergaul dengan berbagai perkembangan terkait dengan dinamika pemikiran hukum dan praktek-praktek kenegaraan di dunia kontemporer, baik melalui jurnal-jurnal ilmiah maupun banyaknya buku baru serta melalui internet tentu tidak akan merasa asing dengan istilah green economy tersebut.). Ada dua alasan mengapa konsep green constitution dan ecocracy menjadi sangat penting untuk dipahami dan diperhatikan oleh segenap komponen bangsa Indonesia. Pertama, terhadap kondisi kelestarian seyogyanya meletakkan dan memperkuat kembali dasardasar konseptual mengenai permasalahan lingkungan hidup dan pembangunan berkelanjutan (sustainable development) dengan berwawasan lingkungan. Kedua, 
UUD 1945 sebagai the supreme law of the land, pada dasarnya telah memuat gagasan dasar mengenai kedaulatan lingkungan dan ekokrasi yang dapat disetarakan dengan nilai-nilainya dengan konsep demokrasi dan nomokrasi (Lutfi, 2011). Alam dimaknai dan diakui memiliki kedaulatannya sendiri, sehingga disamping rakyat sebagai manusia yang dianggap berdaulat, alam pun berdaulat. inilah hakikat yang dimaksukan dengan prinsip kedaulatan lingkungan yang terkandung dalam UUD 1945.

\section{Simpulan}

Pasal 33 ayat 4 UUD 1945 berupaya mengintegrasikan pengembangan ekonomi dengan isu-isu demokrasi, solidaritas, efisiensi, keadilan, berkelanjutan dan prinsip-prinsip lingkungan lainnya. Pasal 33 Ayat 4 UUD 1945 masih diinformasikan ke dalam bahasa yang bersifat umum sehingga membutuhkan penjabaran lebih lanjut dalam bentuk aturan yang lebih rendah dan atau membutuhkan interpretasi dari pengadilan. Pasal $28 \mathrm{H}$ Ayat 1 UUD 1945 lebih lanjut menyebutkan bahwa, "setiap orang berhak hidup sejahtera lahir dan batin, bertempat tinggal dan mendapatkan lingkungan hidup yang baik dan sehat serta berhak memperoleh pelayanan kesehatan". Pasal $28 \mathrm{H}$ Ayat 1 UUD 1945 secara tegas menyatakan pengakuan Indonesia atas hak-hak lingkungan sebagai bagian dari hak-hak dasar (hak asasi manusia) masyarakat Indonesia. Keberadaan Pasal 28 H Ayat 1 UUD 1945 ini untuk menunjukkan bahwa konstitusionalisasi.

\section{Daftar Pustaka}

Albert Gore, 1995, Marine Degradation from Land Based Activities: A Global Concern, Artikel dalam U.S. Department of States Dispatch, Vol. 6: No. 46.

Amartya Sen, 2009, The Idea of Justice, The Belknap Press of Harvard University, Cambridge, Massachusetts.

Brian Z Tamanaha, 2001, A General Jurisprudence of Law And Society, Oxford University Press, New York.

Bryan A. Garner (ed), 2011, Black's Law Dictionary; Second Pocket Edition, St. Paul, Minn:West Group.

Departemen Pendidikan dan Kebudayaan, 1999, Kamus Besar Bahasa Indonesia, PT. Balai Pustaka.

Felicity Millner, 2003, Acces to Environmental Justice, Deakin Law Review, Vo. 16, No. 1.

Fritjof Capra, 1996, The Web of Life. A New Scientific Understanding of Living Systems, Anchor Book, New York.

Fritjof Capra, 2003, The Hidden Connections, Flamingo, London.

Gayatri R. Lilley, 1999, Demokrasi Pengelolaan Sumber Daya Alam, Prosiding Lokakarya Reformasi Hukum di bidang Pengelolaan Sumber Daya Alam, Cetakan I, ICEL, Pustaka Pelajar Offset.

Hendry Roris P. Siahaan, 2018, Ini Data Baru Kewilayahan Laut Indonesia, Gatra.com 10 Agustus 2018, https:/ /www.gatra.com/ru briknasional/337332-Ini- 
Data-Baru-KewilayahanLaut- Indonesia, Diunduh 10 Agustus 2018, pukul 21.20 WIB.

http:/ / prasetya.ub.ac.id/berita/Ke menterian-KelautanGandeng-UB-TerapkanBlue-Economy- 9389-id.htm, Jimly Asshiddiqie, 2009, Green Constitution: Nuansa Hijau Undang-undang Dasar Negara Republik Indonesia Tahun 1945, PT Raja Grafindo Persada, Jakarta.

Lawrence M. Friedman dalam bukunya The Legal System: A Sociology SciencePerspective, dalam Soerjono Soekanto, et. all., 1986, Kriminologi Suatu Pengantar, Ghalia Indonesia, Jakarta.

Lawrence M. Friedman, 2001, Hukum Amerika: Sebuah Pengantar (American Law An Introduction), Penerjemah oleh Wishnu Basuki, PT. Tatanusa, Jakarta.

Mangku, D. G. S. (2010). Pelanggaran terhadap Hak Kekebalan Diplomatik (Studi Kasus Penyadapan Kedutaan Besar Republik Indonesia (KBRI) di Yangon Myanmar berdasarkan Konvensi Wina 1961). Perspektif, 15(3).

Mangku, D. G. S. (2011). Peluang dan tantangan ASEAN dalam penyelesaian sengketa Kuil Preah Vihear di perbatasan Kamboja dan Thailand. Pandecta: Research Law Journal, 6(2).

Mangku, D. G. S. (2012). Suatu Kajian Umum tentang Penyelesaian Sengketa Internasional Termasuk di
Dalam Tubuh

ASEAN. Perspektif, 17(3). Mangku, D. G. S. (2013). Kasus Pelanggaran Ham Etnis Rohingya: Dalam Perspektif ASEAN. Media Komunikasi FIS, 12(2).

Mangku, D. G. S., \& Itasari, E. R. (2015). Travel Warning in International Law Perspective. International Journal of Business, Economics and Law, 6(4).

Marhaeni Ria Siombo, 2010, Hukum Lingkungan dan Pelaksanaan Pembangunan Berkelanjutan di Indonesia, PT Gramedia Jakarta Utama, Jakarta.

Media Keuangan, Transparansi Informasi Kebijakan Fiskal, 2015, Ekonomi Biru, Harapan Baru Konsep Pembangunan yang Ramah terhadap Alam Potensi menjadi Landasan Program dan Kebijakan di Sektor Maritim, Volume X, Nomor 91, April 2015.

Michael Vincent McGinnis, A Rehearsal to Bioregionalism, dalam Michael Vincent McGinnis, 1999, Bioregionalism, Routledge, London-New York.

Mudakir Iskandarsyah, 2008, Pengantar Ilmu Hukumdan Tata Hukum Indonesia, Sagung Seto, Jakarta.

Mukhlis dan Mustafa Lutfi, 2011, Ekologi Kontitusi: Antara Rekonstruki, Investasi atau Eksploitai Atas Nama NKRI, Jurnal Konstitusi, Vol. 8 Nomor 3 Juni 2011.

Paul Scholten, 1935, Algemeen deel, W.E.J. Tjenk Willink, Zwolle dalam

Sudikno 
Mertokusumo.

Purwanto, H., \& Mangku, D. G. (2016). Legal Instrument of the Republic of Indonesia on Border Management Using the Perspective of Archipelagic

State. International Journal of Business, Economics and Law, 11(4).

Purwendah, E., Mangku, D., \& Periani, A. (2019, May). Dispute Settlements of Oil Spills in the Sea Towards Sea Environment Pollution. In First International Conference on Progressive Civil Society (ICONPROCS 2019). Atlantis Press.

Robert D. Bullard, 1994, Environmental Justice for All, dalam Robert D. Bullard, 1994, Environmental Justice and Communities of Color, Club Books, San Fransisco.

Robert R. Kuehn, 2000, A taxonomy of Environmental Justice, Environmental Law Reporter, Vol. 30

Robert W. Collin, 2008, Environmental Justice in Oregon: It's The Law: Environmental Law, Vol. 38. Satjipto Rahardjo, 2010, Ilmu Hukum, Citra Aditya Bakti, Bandung.

Sudikno Mertokusumo, 1999, Mengenal Hukum (Suatu Pengantar), Liberty, Yogyakarta.

Syamsul Bachrie, 2011, Perlindungan Hukum terhadap Lingkungan Hidup Melalui sarana KTUN (Suatu Studi Perizinan Sebagai Pembatasan Hak-Hak Dasar bagi Pengelolaan Lingkungan), Pustaka Pena Press, Makasar. Y. Slamet et.al., 2007, Pendidikan Nilai Pancasila, Unpar Press, Bandung. 